\title{
In Memoriam: Joël Thoraval (1950-2016)
}

\section{Sébastien Billioud}

Translator. Jonathan Hall

\section{(2) OpenEdition}

\section{Journals}

Electronic version

URL: http://journals.openedition.org/chinaperspectives/7011

DOI: 10.4000/chinaperspectives.7011

ISSN: 1996-4617

\section{Publisher}

Centre d'étude français sur la Chine contemporaine

\section{Printed version}

Date of publication: 1 September 2016

Number of pages: $3-4$

ISSN: 2070-3449

\section{Electronic reference}

Sébastien Billioud, «In Memoriam: Joël Thoraval (1950-2016) », China Perspectives [Online], 2016/3 |

2016, Online since 01 September 2016, connection on 15 September 2020. URL : http://

journals.openedition.org/chinaperspectives/7011

(c) All rights reserved 


\title{
In Memoriam:
}

\section{Joël Thoraval (1950-2016)}

\author{
SÉBASTIEN BILLIOUD
}

$\mathrm{O}$ n 7 March 2016, Joël Thoraval left us, struck down in a few weeks by a devastating cancer that was unfortunately discovered too late. In him sinology has lost an outstanding researcher whose brilliant insights, boundless intellectual curiosity, and encyclopaedic knowledge of a wide range of cultural universes sustained his profoundly original thinking. He will also be remembered by his colleagues and friends as a subtle mind with a ready wit and as a fundamentally modest man.

Joël Thoraval was born in Brest in 1950. After his undergraduate days marked by the militant atmosphere of 1968, he enrolled at the École Normale Supérieure in Paris, where he was particularly keen to attend the lectures by Maurice Godelier, to whom he always remained close, while at the same time he continued his studies in philosophy and history. His attraction to Central Asia led him to train himself in archaeology and the languages of that region (Sogdian, Pehlevi, but also Russian), and for his doctorate he left to work as an archaeologist on the Hellenistic site of Aï-Khanoum in Afghanistan. He was to spend several years there, as a researcher at the French Archaeological Delegation. His stay was interrupted in 1980 by the Soviet invasion, which put a brutal end to his first scientific project. A combination of circumstances then gave him the chance to leave for China, where he began by pursuing his studies in Shanghai before taking up various posts: as Cultural Attaché in Beijing (1981-1984), as a research fellow at the Chinese University of Hong Kong (1984-1991), and then as Cultural Councillor in Hong Kong. In this last position he played a major role in helping Michel Bonnin to set up the CEFC and Perspectives chinoises/China Perspectives. In 1994 he left Asia to join the EHESS China Centre in Paris.

Joël Thoraval's research on China developed through several main stages. The first of these was devoted to ethnological work in the northwest of Hainan Island, among a population officially classified as Han but offering nonetheless several striking features. This gave rise to a series of studies on the problem of "nationality" and on relationships of "ethnicity" within the Chinese world. He analysed these by approaching them through a range of diverse cultural practices, whether based on kinship (lineages), on religion, or on gender relations (with his study on the phenomenon of "amorous nocturnal visits"). Some of these studies have become classics for generations of students, such as "'Ethnicity' as Applied to the Chinese Cultural World," first published in Perspectives chinoises in 1999.

His long stay in Hong Kong, at the Chinese University's New Asia (Xinya) College, allowed him to gain acute insights into the Chinese intellectual world, and especially into the academic communities rethink- ing Confucian traditions in the light of modern Western philosophy. This gave rise to his twofold interest in the modern Chinese reception of Western ideas and in the ways in which traditional Confucian teachings are currently categorised, theorised, and put into practice. A stay in Japan between 2000 and 2002 enabled him to bring a comparative perspective to bear on his reflections.

In addition to his incisive articles on the intellectual debates in mainland China (such as "The politics of memory," "The dreamt tradition," and "Historical consciousness and social imaginary"), which demonstrate his gift for perceiving and closely analysing the spirit of an age, his work also focused on Confucian thought in the twentieth century with particular attention to the philosopher Mou Zongsan (1909-1995). He was the first to introduce this thinker to the French public (see especially his "Ideal of the sage and philosophical strategy: An introduction to the thought of Mou Zongsan"). Mou Zongsan was of special interest to him as the ideal embodiment of a type of "philosophical fate" of contemporary Confucianism while also being an indispensable thinker for understanding the reception of Kant in China. Joël Thoraval worked extensively on this reception, as well as on that of Hegel, Schelling, Weber, Strauss, and Schmitt, along with the influence of American pragmatism in China. He has left us writings of lasting importance ("The issue of intellectual intuition and contemporary Confucian philosophy," "From magic to 'Reason': Hegel and religion in China," "The temptation of pragmatism in contemporary China", etc.), as well as some that are unfortunately unfinished.

The last phase of his research turned towards the current resurgence of popular Confucianism in China. This project, which gave me the chance to work with him for about ten years, first arose when the very idea of a popular Confucianism was still far from being accepted. Starting from the hypothesis that a tradition as ancient as Confucianism could not always remain a "wandering soul," as the historian Yu Yingshih put it (Yu meant by this a tradition severed from its former practices), the decision was made to carry out some investigative fieldwork in order to get a clear view of the situation. Joell Thoraval was particularly enthused by the idea of uncovering a "lived Confucianism" within society. In this he was making a certain reconnection, far from the academic Confucianism, with his former fieldwork in Hainan among the village communities that had retained some ancient rituals and kinship patterns of behaviour. The fruits of this labour were several publications by four hands. These emerged from some invigorating sessions in which the exchange of ideas was often coloured by his delightful sense of humour familiar to all his friends and colleagues. 
Finally, no account of Joël Thoraval's intellectual trajectory could fail to mention his seminars at the EHESS, which were so well attended, much beyond student circles, that it was often difficult to find a place. He took great pleasure in presenting some of these seminars jointly with colleagues and close friends (Elisabeth Allès, Anne Cheng, and Michel Bonnin), and they often ended up as lively discussions in neighbouring cafés. Communicating his knowledge was truly important to him, and his teaching had a wide impact. Although he did not have the time to complete the various publication projects for which his seminars were a preparation, he nonetheless leaves behind an important body of work. A posthumous volume incorporating his major texts will appear in 2017.

I Translated by Jonathan Hall.

I Sébastien Billioud is professor of Chinese studies at Paris Diderot University (sebastien.billioud@univ-paris-diderot.fr).

\section{Works cited:}

D "Politique de la mémoire : les intellectuels chinois entre célébration et réflexion" (The politics of memory: Chinese intellectuals between celebration and reflexion), Bulletin de Sinologie, No. 58, 1989, pp. $21-27$ (first part); No. 59, 1989, pp. 14-22 (second part); No. 60, 1989, pp. 18-24 (third part).

D "La tradition rêvée : réflexions sur L'Élégie du Fleuve de Su Xiaokang" (The dreamt tradition: Reflexions on Su Xiaokang's River Elegy), L'infini, No. 30, 1989, pp. $146-168$.

D "Conscience historique et imaginaire social : le débat intellectuel des décennies 1980 et 1990" (Historical consciousness and social imaginary: Intellectual debate in the 1980s and 1990s), Esprit, No. 302, 2004, pp. 171-183.

D "'Ethnicity' as Applied to the Chinese Cultural World," China Perspectives, No. 25, 1999, pp. 44-59.

D "Idéal du sage, stratégie du philosophe, introduction à la pensée de Mou Zongsan" (Ideal of the sage and philosophical strategy: An introduction to the thought of Mou Zongsan), in Mou Zongsan, Spécificités de la philosophie chinoise (The specificities of Chinese philosophy), Paris, Éditions du Cerf, 2003, pp. 7-60.

D "De la magie à la 'raison' : Hegel et la religion chinoise" (From magic to "Reason": Hegel and religion in China), in Michel Cartier (ed.), La Chine entre amour et haine (China between love and hatred), Paris, Desclée de Brouwer, 1998, pp. 113-141.

D "La question de l'intuition intellectuelle et la philosophie confucéenne contemporaine" (The issue of intellectual intuition and contemporary Confucian philosophy), Revue internationale de philosophie, No. 2, 2005, pp. 231-245.

D "La tentation pragmatiste dans la Chine contemporaine" (The temptation of pragmatism in contemporary China), in Anne Cheng (ed.), La pensée chinoise aujourd'hui (Chinese thought in our time), Paris, Gallimard, 2007, pp. 103-134.

The editorial committee of China Perspectives would also draw our readers' attention to the homage by Michel Bonnin, "Adieu, camarade !", published on 22 March 2016 in the Carnets du Centre Chine, http://cecmc.hypotheses.org/27462. 